\title{
ARCHEOLOGIA W CHMURZE PUNKTÓW. PORÓWNANIE REZULTATÓW FILTRACJI I KLASYFIKACJI GRUNTU W PROJEKCIE ISOK Z WYNIKAMI OPRACOWANYMI W OPROGRAMOWANIU LAStools I TERRASOLID
}

\author{
ARCHAEOLOGY IN THE POINT CLOUD. \\ COMPARING RESULTS OF FILTRATION AND CLASSIFICATION \\ OF THE GROUND POINTS IN ISOK PROJECT \\ WITH RESULTS OBTAINED WITH LASTools \\ AND TERRASOLID SOFTWARE
}

Grzegorz Kiarszys, Grzegorz Szalast

Katedra Archeologii IHiSM, Uniwersytet Szczeciński

ul. Krakowska 71-79, 71-017 Szczecin, Poland

\begin{abstract}
This paper is an attempt to compare selected software options for processing of LiDAR data. It is focused on filtration and classification of the ground points for the purpose of archaeological sites identification. We confronted popular commercial Terrasolid software with LAStools released under the LGPL license. To accomplish this task we used data gathered in the frame of ISOK project (Computerized Information System of Country Protection from Extraordinary Hazards), implemented in Poland several years ago. In order to examine the effectiveness of the software algorithms we selected well-known archeological sites of various landforms (barrows, megaliths, hill forts) to perform the test. Obtained results were compared with the classification provided within the source data of the ISOK project. It allowed us to indicate the advantages and disadvantages of each tested solutions.
\end{abstract}

\section{WSTĘP}

Każda próba wykorzystania nowej metody pociąga za sobą potrzebę jej krytyki. Zdobyte w ten sposób doświadczenia okazują się niezbędne w procesie interpretacji rezultatów badań. Upowszechnienie się w ostatnich latach lotniczego skaningu laserowego (ang. ALS - Airborne Laser Scanning) stworzyło dla archeologii nowe źródło informacji o olbrzymim potencjale. Lotniczy LiDAR daje możliwość uzy- 
skania precyzyjnych i posiadających georeferencję pomiarów 3D ${ }^{1}$. Pozwala na badanie obszarów, dla których wcześniej archeologia nie dysponowała wystarczająco skutecznymi metodami. Może być zastosowany do odwzorowania szczegółowej topografii terenów leśnych i ujawniania niedostępnych dotychczas stanowisk. Za jego pomocą tworzy się wizualizacje reliktów zabytków archeologicznych, które prawie całkowicie utraciły własną formę terenową i obecnie są już niewidoczne z poziomu gruntu ${ }^{2}$. Umożliwia także rejestrację intensywności odbicia, która w określonych warunkach może być użytecznym źródłem wiedzy ${ }^{3}$.

Należy jednak podkreślić, że zobrazowania tworzone z użyciem danych ALS są przede wszystkim uogólnionym statystycznie, geometrycznym obrazem przestrzeni. Obraz taki poddawany jest określonym zabiegom w celu uzyskania jak najbardziej perswazyjnej wizualizacji obiektów kulturowych. W niektórych okolicznościach poprawność ich geometrycznego odwzorowania może być wręcz traktowana jako kwestia drugorzędna ${ }^{4}$. Na jakość uzyskanych danych ma wpływ wiele czynników, spośród których jedynie część jest uzależniona od podjętych przez archeologa decyzji. Pod uwagę należy brać m.in. takie okoliczności, jak: rodzaj i model użytego skanera, średnia gęstość skanowania, pułap lotu, stan wegetacji, zachmurzenie, pokrywa śnieżna, obecność wody, pyłu czy wreszcie specyfikę terenu, który ma zostać poddany skanowaniu, oraz złożoność obiektów itd. ${ }^{5}$. Komputerowe przetwarzanie danych ALS ma także charakter subiektywny. Implikuje konieczność dokonywania wyborów, które mają determinujący wpływ na uzyskany efekt końcowy ${ }^{6}$. Już na tym wstępnym etapie następuje redukcja możliwych do zebrania informacji.

W niniejszym artykule zostaną omówione wybrane zagadnienia związane z obróbką danych ALS i ich prezentacją. Celem będzie przede wszystkim ocena przydatności darmowego oprogramowania do klasyfikacji i obróbki chmury punktów (ang. point cloud) pozyskanych w trakcie lotniczego skanowania laserowego. Konfrontacji zostaną poddane pliki sklasyfikowane w programie LAStools, a punktem odniesienia będą dla nich dane opracowane w komercyjnym pakiecie oprogramowania Terrasolid. Autorzy niniejszego artykułu zamierzają skupić się jedynie na klasie gruntu i atrybucie wysokości. Obrazy rastrowe zostaną wygenerowane w programie QuantumGIS.

Jako źródło danych ALS posłużą pliki LAS uzyskane w ramach projektu ISOK (Informatyczny System Osłony Kraju przed nadzwyczajnymi zagrożeniami). Są one

\footnotetext{
${ }^{1}$ Np. Cowley, Opitz 2013, 1; Korzeniowska, Łącka 2011, 271; Kraus, Pfeifer 2001; Michalik 2009, 33, 34; Opitz 2013, 13, 16, 17; Pietrzak 2012, 9-16; Wężyk 2006, 120, 121.

${ }^{2}$ Np. Bewley, Crutchley, Shell 2005; Devereux, Amable, Crow, Cliff 2005; Challis, Kokalj, Kincey, Moscrop, Howard 2008; Doneus, Briese 2011; Risbøl 2013; Sławik, Zapłata 2011.

${ }^{3}$ Crutchley, Crow 2009, 7, 8; Challis, Howard 2013.

${ }^{4}$ Np. Devereux, Amable, Crow 2008; Krištof, Zakšek, Kokalj 2013.

${ }^{5}$ Szadkowski 2012, 15; Wężyk 2006, 121.

${ }^{6}$ Doneus, Kühteiber 2013, 33-35; Opitz 2013, 13, 20, 22.
} 
udostępniane przez Centralny Ośrodek Dokumentacji Geodezyjnej i Kartograficznej w formie sklasyfikowanej już chmury punktów, której poprawność zostanie porównana $\mathrm{z}$ rezultatami uzyskanymi w oprogramowaniu LAStools i Terrasolid ${ }^{7}$.

Analizie będą poddane wybrane przykłady znanych stanowisk archeologicznich - ze względu na to, iż nie ma większych wątpliwości dotyczących ich lokalizacji oraz specyfiki. W ten sposób można ograniczyć ewentualne zastrzeżenia co do uzyskanych zobrazowań i ułatwić ich identyfikację z obiektami archeologicznymi w terenie. Ponadto, badany obszar został celowo ograniczony do arbitralnie określonego, najbliższego kontekstu stanowisk archeologicznych. Podjęto taką decyzję, gdyż chodzi przede wszystkim o poprawność odwzorowania konkretnych zabytków archeologicznych i ewentualne błędy, które mogą pojawić się na tym etapie pracy $\mathrm{z}$ danymi. Współczesne, antropogeniczne obiekty, takie jak np.: rowy, drogi, granice pól, budynki, wiadukty itp., mogą okazać się złożonym problemem dla zastosowanych algorytmów ${ }^{8}$. Wymienione tu elementy krajobrazu mogą także dostarczyć istotnych informacji dla celów archeologiczych (np. procesy podepozycyjne, cele konserwatorskie, planowanie przestrzenne), jednak nie są one głównym przedmiotem tej pracy. Oczywiście, nawet na tak ograniczonych przestrzennie obszarach będą się one pojawiać w sposób nieunikniony.

\section{CHMURA PUNKTÓW, FILTRACJA ODBIĆ GRUNTU, METODA AKTYWNEGO MODELU TIN}

Dane ze skaningu laserowego udostępniane są najczęściej w postaci nieregularnej chmury punktów. Każdy z nich ma przypisane atrybuty x, y, z, które określają lokalizację w układzie współrzędnych płaskich (X, Y) oraz wysokość (Z). Poszczególne punkty mogą zawierać też inne informacje na temat odbicia (np. intensywność, czas GPS, liczba odbić itp.) (Pietrzak 2012,13).

Chmura punktów przedstawia jedynie te miejsca, od których odbiły się impulsy lasera $^{9}$ (Crutchley, Crow 2009, 8-9). W związku z tym może zaistnieć sytuacja, w której ze względu na różne okoliczności (np. gęstość skanowania, warunki terenowe, właściwości powierzchni skanowanego obiektu) niektóre obiekty znajdujące

\footnotetext{
${ }^{7}$ Część danych udostępnionych w ramach projektu ISOK została także opracowana z wykorzystaniem pakietu Terrasolid. W takim przypadku to porównanie pozwoli wykazać, czy za pomocą tego samego narzędzia, wykorzystując inne ustawienia oraz korektę manualną, da się uzyskać bardziej satysfakcjonujące rezultaty z punktu widzenia archeologii.

${ }^{8}$ Por. np. Pietrzak 2012, 56, 66.

${ }^{9}$ Sygnał wysłany przez skaner może ulec rozszczepieniu, tworząc wiele odbić. Nie wszystkie powracające odbicia są rejestrowane przez urządzenie. Niektóre echa i zakłócenia są interpretowane i usuwane (por. np. Wężyk 2006, 122-124).
} 
się na ziemi wcale nie zostaną zeskanowane, a inne odwzorowane w sposób niepełny lub błędny. Wykonane przez skaner pomiary są nieuporządkowanym zbiorem informacji na temat różnych kategorii obiektów, w którym nakładają się na siębie odbicia pochodzące np. z dachów i ścian budynków, szaty roślinnej, poziomu gruntu, brzegów cieków wodnych i innych przeszkód terenowych. Za pomocą określonych metod matematycznych, w procesie filtracji i klasyfikacji, poszczególne punkty zostają przypisane do konkretnych kategorii, co ułatwia dalszą pracę $\mathrm{z}$ danymi.

Binarne pliki LAS są najpopularniejszym obecnie formatem służącym do przechowywania chmury punktów pochodzących ze skanowania ALS. Zgodnie z ogólnie przyjętym dla tego formatu standardem, określonym przez American Society of Photogrammetry and Remote Sensing (ASPRS) ${ }^{10}$, omawiane kategorie opisywane są zgodnie z poniższym schematem ${ }^{11}$ :

0 . Created, Never Classified - Utworzone, nigdy nieklasyfikowane

1. Unclassified - Bez klasyfikacji

2. Ground - Grunt

3. Low Vegetation - Niska szata roślinna

4. Medium Vegetation - Rośliny o średniej wysokości

5. High Vegetation - Wysoka szata roślinna

6. Buildings - Budynki

7. Low Point (Noise) - Niskie punkty (szum)

8. Model Key-Point - Punkty kluczowe terenu

9. Water - Woda

10-11. Reserved for ASPRS Definition - Zarezerwowane przez ASPRS12. Overlap Points - Punkty służące do dopasowania sąsiadujących skanów

13-31. Reserved for ASPRS Definition - Zarezerwowane przez ASPRS.

Jak zaznaczono na wstępie, w poniższym artykule zostanie omówiona przede wszystkim poprawność wyodrębnienia klasy 2., reprezentującej odbicia gruntu. Nie istnieje obecnie narzędzie, za pomocą którego można by było dokonać całkowicie bezbłędnej klasyfikacji ${ }^{12}$. Testowane w niniejszej pracy programy wykorzystują do tego celu metodę aktywnego modelu TIN (ang. Triangulated Irregular Network). Została ona zaproponowana przez Petera Axelssona ${ }^{13}$. W dużym uproszczeniu polega ona na wykorzystaniu siatki nieregularnych trójkątów, która jest generowana na podstawie chmury punktów. Algorytm tworzy początkowo rzadką siatkę trójkątów, której struktura opiera się na punktach inicjalnych seed. Są to punkty, co do których istnieje największe prawdopodobieństwo, że reprezentują odbicia gruntu.

\footnotetext{
${ }^{10} \mathrm{http} / / / \mathrm{www}$. asprs.org/

${ }^{11}$ Pietrzak 2012, 16-18.

${ }^{12}$ Hug, Krzystek, Fuchs 2004, 836.

${ }^{13}$ Axelsson 2000.
} 
Następnie siatka jest stopniowo zagęszczana. Dodawane są do niej kolejne punkty spełniające warunki progowe. Na ich podstawie tworzone są dalsze trójkąty. Wartości progowe będą różniły się w zależności od rodzaju terenu, którego dotyczą. Są one definiowane przede wszystkim w oparciu o odległość do płaszczyzny oraz kąty do wierzchołków. Inaczej będzie przebiegała filtracja przestrzeni otwartych czy zalesionych, a inaczej obszarów zabudowanych, gdzie ze względu na występowanie nieciągłości procedura ta ulega dalszej komplikacji ${ }^{14}$. Mimo że liczba punktów gruntu ma bezpośredni wpływ na uzyskane obrazy rastrowe, wcale nie musi ona decydować o jakości samego zobrazowania. Więcej punktów może oznaczać także więcej błędnych pomiarów zaklasyfikowanych do kategorii gruntu. Wreszcie, wykorzystanie algorytmu, który filtruje punkty w „ostrożny” sposób, może, mimo relatywnie mniejszej ich liczby, pozytywnie wpłynąć na geometryczną poprawność odwzorowania.

\section{ISOK - ŹRÓDŁO DANYCH PORÓWNAWCZYCH}

Jednym z celów niniejszej pracy jest sprawdzenie przydatności dla zastosowań archeologicznych danych ze skaningu laserowego uzyskanych w ramach programu „Informatyczny System Osłony Kraju przed nadzwyczajnymi zagrożeniami” (ISOK). Przedsięwzięcie to realizowane jest przez konsorcjum składające się z następujących instytucji państwowych: Instytut Meteorologii i Gospodarki Wodnej - Państwowy Instytut Badawczy, Krajowy Zarząd Gospodarki Wodnej, Główny Urząd Geodezji i Kartografii, Instytut Łączności - Państwowy Instytut Badawczy, Rządowe Centrum Bezpieczeństwa w ramach programu „Innowacyjna Gospodarka”. Produkty z ISOK-u udostępniane są odpłatnie przez Centralny Ośrodek Dokumentacji Geodezyjnej i Kartograficznej ${ }^{15}$. Tam też można otrzymać informacje dotyczące dostępności i ogólnej charakterystyki oferowanych danych. Spośród całego wachlarza gotowych produktów cyfrowych autorzy artykułu skupili się jedynie na chmurze punktów w formacie LAS.

Lotniczy skaning laserowy w ramach ISOK-u został wykonany w dwóch standardach. Średnia gęstość skanowania w standardzie I wynosiła 4 lub $6 \mathrm{pkt} / \mathrm{m}^{2}$, natomiast $\mathrm{w}$ standardzie II $-12 \mathrm{pkt} / \mathrm{m}^{2}$. Standard II został ograniczony przede wszystkim do wybranych obszarów miejskich. Większość danych jest dostępna w standardzie I. Pliki z chmurami punktów zostały sprowadzone do układu współrzędnych płaskich prostokątnych PUWG 1992 i podzielone na odpowiadające mu arkusze. Pliki LAS w standardzie I pokrywają się z arkuszami w układzie „1992”

\footnotetext{
${ }^{14}$ Pietrzak 2012, 22.

${ }^{15}$ Królikowski 2012, 19, 20.
} 
w skali $1: 2500$, co stanowi $1 / 16$ arkusza $1: 10000$, czyli obszar $1 \mathrm{~km} \times 1 \mathrm{~km}$. Dane w standardzie II są natomiast podzielone na arkusze pokrywające się z mapami w skali $1: 1250$, co stanowi $1 / 64$ arkusza $1: 10000$, i przedstawia powierzchnię ok. $0,5 \mathrm{~km} \times 0,5 \mathrm{~km}$. Jak można dowiedzieć się ze strony internetowej CODGiK ${ }^{16}$, pliki zawierają także informacje o intensywności odbicia. Udostępniona chmura punktów jest już sklasyfikowana. Według instytucji udostępniającej dane poprawność klasyfikacji nie powinna być niższa niż $95 \%{ }^{17}$. Wyodrębnione klasy zgodnie $\mathrm{z}$ deklarowaną informacją ze strony internetowej przedstawiają się w następujący sposób:

1. Punkty przetwarzane, ale niesklasyfikowane

2. Punkty leżące na gruncie

3. Punkty reprezentujące niską wegetację, tj. w zakresie $0-0,40 \mathrm{~m}$

4. Punkty reprezentujące średnią wegetację, tj. w zakresie $0,40-2,00 \mathrm{~m}$

5. Punkty reprezentujące wysoką wegetację, tj. w zakresie powyżej $2,00 \mathrm{~m}$

6. Punkty reprezentujące budynki, budowle oraz obiekty inżynierskie

7. Szum

8. Punkty reprezentujące obszary pod wodami.

Nasze zainteresowanie ISOK-iem podyktowane jest przede wszystkim relatywnie niskimi, w porównaniu ze zorganizowaniem specjalnego nalotu fotogrametrycznego, kosztami uzyskania danych. Dostępne produkty cyfrowe pokrywają znaczne połacie kraju, ponieważ skanowanie obszarów zagrożonych zostało wykonane z dużym marginesem. Należy jednak pamiętać, że program ISOK ma przede wszystkim na celu poprawę bezpieczeństwa kraju i został wykonany pod kątem modelowania zagrożeń naturalnych (głównie: przewidywanie zagrożenia powodziowego). W związku z tym należy się spodziewać, że w niektórych okolicznościach rozdzielczość standardu I może okazać się niewystarczająca dla potrzeb archeologicznych. Oprócz tego, w planowaniu nalotów w ograniczonym stopniu brano pod uwagę współczynnik penetracji szaty roślinnej ${ }^{18}$, który jest najkorzystniejszy późną jesienią oraz wczesną wiosną ${ }^{19}$. Może to spowodować, że szczególnie na obszarach zalesionych, które zostały zeskanowane wiosną lub latem, liczba impulsów lasera, które dotarły do powierzchni gruntu, będzie zbyt niska, by odwzorować mniejsze obiekty archeologiczne. Należy także założyć, że klasyfikacja chmury punktów nie została wykonana pod kątem identyfikacji obiektów archeologicznych i przyporządkowania ich do kategorii gruntu. Dlatego jeżeli uda się dzięki niej zi-

\footnotetext{
${ }^{16} \mathrm{http} / / /$ www.codgik.gov.pl/zasob/372-numeryczne-dane-wysokosciowe.html

${ }^{17}$ Szadkowski 2012, 16, 17.

${ }^{18}$ Specyfikacja ISOK precyzuje, iż naloty w Standardzie I powinny być wykonywane od połowy października do końca kwietnia. Natomiast dla Standardu II występuje jedynie sugestia, by unikać okresów intensywnej wegetacji.

${ }^{19}$ Crutchley, Crow 2009, 33.
} 
dentyfikować konkretne relikty kulturowe, będzie to świadczyło bardziej o doskonałości algorytmów wykorzystanych do automatycznej filtracji i klasyfikacji niż o tym, że zostały one celowo opracowane w taki sposób.

\section{OPROGRAMOWANIE WYKORZYSTANE DO KLASYFIKACJI I FILTRACJI CHMURY PUNKTÓW}

Na potrzeby testów wykorzystane zostało oprogramowanie - Terrasolid (wersja 012.004) oraz LAStools (wersja 130623). Terrasolid jest pakietem aplikacji rozpowszechnianym na licencji oprogramowania zamkniętego. Obecnie, oprócz aplikacji LP360 dystrybuowanej przez firmę Qcoherent, jest jednym z najczęściej stosowanych i najbardziej rozbudowanych komercyjnych narzędzi do pracy z danymi LiDAR. Spośród wszystkich aplikacji dostępnych w pakiecie Terrasolid zostaną wykorzystane dwie: TerraScan oraz TerraModeler ${ }^{20}$.

Dostęp do komercyjnego oprogramowania ogranicza przede wszystkim koszt jego zakupu. Stąd też wynika potrzeba sprawdzenia potencjału dostępnych darmowych narzędzi, umożliwiających filtrację i klasyfikację chmury punktów. Alternatywą dla komercyjnego oprogramowania może okazać się wspominany wcześniej LAStools, którego autorem jest Martin Isenburg ${ }^{21}$.

W związku z dużymi możliwościami weryfikacji efektów pracy, jakie daje pakiet Terrasolid, uzyskane w nim klasyfikacje dla poszczególnych chmur punktów, reprezentujących wybrane stanowiska archeologiczne, potraktujemy jako wzorcowe. Poza metodami automatycznej filtracji pakiet ten pozwala na manualne poprawianie pojawiających się błędów, co znacząco podnosi jakość efektu końcowego. Rezultaty pracy zostaną porównane z filtracją i klasyfikacją wykonaną w programie LAStools oraz oryginalną klasyfikacją ISOK.

\section{Filtracja i klasyfikacja kategorii gruntu za pomocą oprogramowania firmy Terrasolid Ltd.}

Aplikacja TerraScan umożliwia między innymi: przeglądanie chmury punktów w 3D, filtrowanie i klasyfikowanie (zarówno za pomocą wybranych algorytmów, jak i manualnie), tworzenie profili oraz edycję i eksportowanie danych do wybranych formatów. Z kolei jedną z podstawowych funkcjonalności TerraModeler jest tworzenie numerycznego modelu terenu w postaci GRID lub TIN. Ponadto dostarcza on rozbudowanych narzędzi do edycji i wizualizacji danych oraz uzyskiwania

\footnotetext{
${ }^{20}$ Zarówno za udostępnienie komercyjnego oprogramowania Terrasolid, jak i za pomoc w obróbce danych autorzy dziękują firmie GISPRO Sp. z o.o.

${ }^{21} \mathrm{http}: / /$ rapidlasso.com/
} 
produktów pochodnych (np. mapy warstwicowej, mapy spadków itd.) ${ }^{22}$. Oprogramowanie firmy Terrasolid Ltd. działa w środowisku CAD (w tym przypadku wykorzystany został Bentley MicroStation V8).

Prace nad zdeklasyfikowaną chmurą punktów, uzyskaną w ramach projektu ISOK, rozpoczęliśmy od wczytania jej w aplikacji Terrascan, do czego konieczne było zdefiniowanie dodatkowej klasy zerowej. Następnym krokiem było znalezienie i sklasyfikowanie błędnie pomierzonych podczas skanowania punktów, tzw. low points. W czasie tej operacji poprzez odpowiednie zdefiniowanie ustawień algorytmu wyeliminowane zostały zarówno punkty pojedyncze, jak i te znajdujące się w niewielkich skupiskach. Następnie przeprowadzono automatyczną ekstrakcję gruntu $\mathrm{z}$ wykorzystaniem zaimplementowanego w oprogramowaniu algorytmu, polegającą na iteracyjnym budowaniu modelu sieci nieregularnych trójkątów. Wyniki tego procesu arbitralnie przeniesiono na warstwę Model-Key-Points, jako pewne punkty gruntu. Po czym powtórzona została procedura klasyfikacji gruntu dla pozostałych punktów, a do wyników dodane zostały punkty sklasyfikowane za pierwszym razem. Po tym etapie możliwe było wyeliminowanie błędnie sklasyfikowanych punktów za pomocą funkcji Below Surface.

Tak przygotowana klasyfikacja gruntu została zweryfikowana manualnie, z wykorzystaniem funkcji generowania serii przekrojów wzdłuż zdefiniowanej ścieżki. Celem tej operacji było usunięcie błędnie sklasyfikowanych punktów gruntu, które wyraźnie odstawały od ,rzeczywistej” powierzchni gruntu - zwrócono przy tym szczególną uwagę na najbliższą okolicę obiektów archeologicznych. Zadanie to ułatwiła możliwość wygenerowania Numerycznego Modelu Terenu w postaci siatki nieregularnych trójkątów (za pomocą aplikacji TerraModeler), na którym wyraźnie widoczne były niedoskonałości klasyfikacji przeprowadzonej za pomocą algorytmu.

Podczas opracowywania zdeklasyfikowanej chmury punktów, uzyskanej w ramach projektu ISOK, próbowaliśmy początkowo wykorzystać automatyczną filtrację gruntu na ustawieniach domyślnych, sugerowanych przez dystrybutora oprogramowania. Jak się okazało, mimo iż większość badanych obszarów teoretycznie spełniała warunki opisane przez producenta, algorytm poprawnie klasyfikował procentowo niedużą część gruntu. Dopiero drobna, stosowna do topografii konkretnego obszaru korekta w ustawieniach filtracji oraz dwukrotne jej przeprowadzenie dały satysfakcjonujące rezultaty.

\section{Filtracja i klasyfikacja punktów gruntu z użyciem programu LAStools}

LAStools jest oprogramowaniem oficjalnie udostępnionym w Internecie. Określona jego część funkcjonuje na licencji LGPL (ang. Lesser General Public Licence). Wybrane aplikacje dostępne są jednak na odpłatnej licencji dla użytku ko-

\footnotetext{
${ }^{22}$ Zob. więcej: Korzeniowska, Łącka 2011, 274-275; Soininen 2011a; 2011 b.
} 
mercyjnego oraz rządowego. Poszczególne skrypty mogą być wykorzystywane za darmo do: celów niekomercyjnych, osobistego użytku, zastosowań niezwiązanych z wojskowością, edukacji lub celów humanitarnych. Program umożliwia m.in. automatyczne filtrowanie i klasyfikowanie chmury punktów, edycję, wizualizację, eksportowanie danych do różnych formatów, w tym tworzenie NMT, generowanie warstwic oraz wiele innych, bardzo przydatnych funkcji ${ }^{23}$. Nielicencjonowana wersja programu dodaje automatycznie do edytowanej chmury punktów niewielki szum. Natomiast w przypadku generowanych obrazów rastrowych szum ma postać równoległych linii komórek pozbawionych przypisanej wartości. Takie ograniczenia zostały celowo wprowadzone przez twórcę programu, by zapobiec wykorzystaniu nielicencjonowanych wersji do zastosowań komercyjnych, które często wiążą się z pracą na dużych pakietach danych. Niedogodności tych można uniknąć, dzieląc pakiety danych na mniejsze fragmenty.

Do klasyfikacji gruntu w programie LAStools służy moduł LASground. Nie oferuje on tak rozbudowanych opcji edycji jak Terrascan. Pozwala modyfikować wybrane parametry kontrolujące proces filtracji i klasyfikacji tylko w ograniczonym zakresie. Można wybierać spośród domyślnych ustawień dla terenów o różnym pokryciu: 1) forrest or hills, 2) town or flats, 3) city or warehouses, 4) metropolis. Oprócz tego istnieje możliwość modyfikowania parametrów odpowiadających za przebieg procesu poprzez linię poleceń. Są nimi step, spike, offset oraz stddev. Step kontroluje proces filtrowania w oparciu o atrybut wysokości. Zbyt duże zmniejszenie jego wartości może spowodować, że gęsta szata roślinna lub niskie budynki zostaną uznane za grunt. Spike służy do usuwania tzw. kolców, czyli pojedynczych punktów znajdujących się ponad lub poniżej gruntu (np. refleks od lecącego ptaka). Offset określa wartość graniczną występowania punktów ponad szacowaną wstępnie powierzchnią gruntu, które następnie zostają do niego włączone. Stddev definiuje wielkość odchylenia standardowego. Można też modyfikować parametr wpływający na precyzję wyszukiwania początkowych punktów terenu ${ }^{24}$.

Pierwszym krokiem w pracy $\mathrm{z}$ danymi ISOK $\mathrm{w}$ oprogramowaniu LAStools było usunięcie pierwotnej klasyfikacji przyz użyciem narzędzia las2las. Następnie za pomocą tej samej aplikacji i funkcji pick wycięto z arkuszy odpowiednie obszary. $\mathrm{Na}$ dalszych etapach pracy wykorzystano jedynie powstałe w ten sposób wycinki chmur punktów. W kilku przypadkach stanowiska występowały na połączeniu różnych arkuszy. W takiej sytuacji zostały one ,sklejone” za pomocą aplikacji lasmerge. Następnie z użyciem lasground (ustawienia forrest or hills, offset 0,1 , ultra) przeprowadzono klasyfikację dla kategorii gruntu. Informacje na temat liczby punktów gruntu uzyskano dzięki aplikacji lasinfo. Natomiast za pomocą funkcji las2dem chmura punktów została wyeksportowana do obrazu rastrowego.

\footnotetext{
${ }^{23}$ Hug, Krzystek, Fuchs 2004; Isenburg 2011; Twardowski, Marmol 2012, 460, 461.

${ }^{24}$ Pietrzak 2012, 42-44.
} 


\section{PRZETWARZANIE CHMURY PUNKTÓW - NMT, NMPT (TIN, GRID)}

W celach interpretacyjnych chmura punktów może zostać przetworzona w numeryczny model terenu (pol. NMT, ang. digital terrain model - DTM) lub numeryczny model pokrycia terenu (pol. NMPT, ang. digital surface model - DSM). NMT tworzony jest na podstawie punktów przypisanych do kategorii gruntu. Jest to więc obraz przedstawiający powierzchnię ziemi, z której cyfrowo „usunięto” roślinność, zabudowania i inne odfiltrowane przez algorytm obiekty. Natomiast NMPT przedstawia całość pokrycia terenu, łącznie ze wszystkimi obiektami, które się na nim znajdują. NMT jest szczególnie użyteczny w archeologii obszarów leśnych. Umożliwia bowiem tworzenie wizualizacji powierzchni ziemi znajdującej się pod szatą roślinną. Jednak, w określonych okolicznościach, algorytmy użyte do filtracji poziomu gruntu mogą powodować „wygładzanie” obiektów archeologicznych. W związku z tym, w przypadku obszarów otwartych, niepokrytych bujną roślinnością, NMPT jest preferowanym źródłem danych ${ }^{25}$.

Jednym ze sposobów prezentacji NMT jest siatka nieregularnych trójkąów (ang. Triangulated Irregular Network - TIN). Jest ona tworzona poprzez połączenie sąsiadujących ze sobą punktów pomiarowych wierzchołkami trójkątów. TIN jest formatem bezstratnym (jeśli nie został celowo zredukowany), ponieważ nie wiąże się z nim potrzeba ingerowania $\mathrm{w}$ wartości zapisane $\mathrm{w}$ chmurze punktów ${ }^{26}$. Tak stworzone zobrazowanie umożliwia dalszą edycję. Można je pokolorować za pomocą wybranej palety kolorów przypisanej do wartości określonego atrybutu (np. wysokości) lub pocieniować, ustalając kąt i kierunek padania światła. Istnieje także możliwość zwiększenia wartości przewyższeń w celu uwypuklenia obiektów, które są nieczytelne w przypadku zachowania rzeczywistych wartości wysokości.

Inną popularną formą prezentacji NMT jest wygenerowanie z chmury punktów obrazu rastrowego. Jest to obecnie najprostszy i najbardziej wydajny format danych, jeżeli chodzi o możliwości edycji i przechowywanie informacji przestrzennych ${ }^{27}$. W związku z tym, że chmura punktów jest $\mathrm{w}$ rzeczywistości zbiorem nieregularnie rozrzuconych w przestrzeni pomiarów, jej konwersja do formatu rastrowego GRID (regularne komórki, najczęściej w kształcie kwadratu) jest złożonym problemem. Wymusza bowiem konieczność interpolowania wartości atrybutu wysokości za pomocą jednej z kilku dostępnych metod (każda z nich daje różne rezultaty). Jeżeli dla określonej komórki istnieje kilka pomiarów (kilka odbić), będą one utracone, ponieważ muszą zostać sprowadzone do jednej wartości. Analogicznie wartości atrybutu wysokości sąsiadujących ze sobą punktów nie zostają automatycznie przeniesione do poszczególnych komórek rastra, ponieważ także i one muszą być interpolowane ${ }^{28}$.

\footnotetext{
${ }^{25}$ Crutchley, Crow 2009, 11; Doneus, Kühteiber 2013, 35-39.

${ }^{26}$ Crutchley, Crow 2009, 8-11; Pietrzak 2012, 20.

${ }^{27}$ Np. Chandra, Zhang, Liu 2008, 81.

${ }^{28}$ Marszalik 2009, 30-32.
} 
Rozdzielczość NMT w formacie GRID powinna być zbliżona do średniej gęstości chmury punktów (tj. liczba komórek rastra powinna być podobna do liczby punktów pomiarowych/metr kwadratowy ${ }^{29}$. Stworzenie modelu o większej rozdzielczości spowoduje sytuację, w której wartości niektórych komórek nie będą pochodziły z bezpośredniego pomiaru, ponieważ będą musiały być obliczone. Natomiast zbyt niska rozdzielczość rastra doprowadzi do niekontrolowanej redukcji danych $^{30}$. Mimo takich ustawień część wartości atrybutu wysokości w sposób nieunikniony zostanie automatycznie wygenerowana. Ze względu na to, iż LiDAR dostarcza pomiarów, które są pseudolosowo rozrzucone w przestrzeni, niektóre komórki mogą mieć kilka odbić, inne nie będą miały żadnego ${ }^{31}$. W naszym porównaniu będziemy przetwarzali jedynie odbicia przypisane do kategorii gruntu. W konsekwencji ograniczona opisanymi czynnikami rozdzielczość obrazu rastrowego uniemożliwi odwzorowanie obiektów, które są mniejsze niż komórka rastra. Natomiast rozpoznanie niewiele większych obiektów (składających się z kilku komórek) może być utrudnione.

Wygenerowany w ten sposób obraz rastrowy może zostać przekształcony za pomocą różnych narzędzi analitycznych, pozwalających na tworzenie szerokiego wachlarza wizualizacji ${ }^{32}$. W niniejszym porównaniu zostaną wykorzystane serie cieniowanych modeli terenu ${ }^{33}$. Należy pamiętać, że komórki obrazu rastrowego, przedstawiającego wymienione wizualizacje, nie przechowują w sobie wartości wysokości, ponieważ została ona przeliczona na atrybut opisujący wartość odbitego światła ${ }^{34}$.

\section{PORÓWNANIE POPRAWNOŚCI KLASYFIKACJI KATEGORII GRUNTU W ODNIESIENIU DO WYBRANYCH STANOWISK ARCHEOLOGICZNYCH}

Na potrzeby artykułu starano się dobrać przykłady porównawcze stanowisk archeologicznych tak, by były one różnorodne pod względem terenu i pory roku, w której zostało wykonane skanowanie LiDAR (por. tab. 1). Konfrontacji poddano zarówno stanowiska z dużymi obiektami, o wyraźnie rysującej się formie terenowej, jak i te mogące sprawić trudności interpretacyjne z powodu obiektów o niewielkich rozmiarach zlokalizowanych w obszarze porośniętym gęstą roślinnością.

\footnotetext{
${ }^{29}$ Chandra, Zhang, Liu 2008, 81.

${ }^{30}$ Florinsky 2002, 482-489.

${ }^{31}$ Pietrzak 2012, 20.

${ }^{32}$ Por. Devereux, Amable, Crow 2008; Hesse 2010; Zakšek, Kokalj, Oštir 2011; Krištof, Zakšek,

${ }^{33}$ Por. np. Krištof, Zakšek, Kokalj 2013, 103-104.

${ }^{34}$ Por. Crutchley 2013, 137-139.
} Kokalj 2013. 
Tabela 1. Stanowiska omówione w artykule oraz podstawowe informacje na temat analizowanych zestawów danych

Table 1. Sites discussed in the article with basic information on analysed data

\begin{tabular}{|l|c|c|c|c|c|}
\hline \multirow{2}{*}{$\begin{array}{c}\text { Stanowisko } \\
\text { archeologiczne }\end{array}$} & Data nalotu & \multirow{2}{*}{$\begin{array}{c}\text { Wymiary } \\
\text { analizowanego } \\
\text { obszaru }\end{array}$} & \multicolumn{2}{c|}{$\begin{array}{c}\text { Całkowita liczba wyodrębnionych punktów } \\
\text { gruntu dla analizowanego obszaru }\end{array}$} \\
\cline { 5 - 7 } & & ISOK & LAStools & \multicolumn{2}{c|}{ Terrasolid } \\
\hline Chruścina & $\begin{array}{c}09.10 .2011 \\
28.10 .2011\end{array}$ & $290 \mathrm{~m} \times 250 \mathrm{~m}$ & 191436 & 206873 & 224209 \\
\hline Kruszyniec & 28.10 .2011 & $130 \mathrm{~m} \times 145 \mathrm{~m}$ & 46365 & 74198 & 74810 \\
\hline Bełcz Mały & 28.10 .2011 & $400 \mathrm{~m} \times 395 \mathrm{~m}$ & 630235 & 640707 & 633819 \\
\hline Wietrzychowice & 01.05 .2011 & $370 \mathrm{~m} \times 305 \mathrm{~m}$ & 239916 & 302845 & 269289 \\
\hline Grzybnica & 03.03 .2012 & $420 \mathrm{~m} \times 630 \mathrm{~m}$ & 387856 & 907496 & 729603 \\
\hline Eupawa 1 & 07.05 .2011 & $830 \mathrm{~m} \times 665 \mathrm{~m}$ & 702615 & 2010924 & 1299325 \\
\hline Eupawa 2 & 30.04 .2011 & $1130 \mathrm{~m} \times 870 \mathrm{~m}$ & 1333688 & 3980719 & 2560709 \\
\hline
\end{tabular}

Wszystkie omawiane stanowiska zostały zeskanowane w Standardzie I ISOK. Oznacza to, że średnia gęstość chmury punktów w analizowanych przykładach nie powinna być niższa niż $4 \mathrm{pkt} / \mathrm{m}^{2}$. Do jej obliczenia brano pod uwagę tylko ostatnie lub ostatnie $=$ pierwsze odbicia, pomijając odbicia pośrednie. $\mathrm{W}$ związku z tym rzeczywista gęstość chmury punktów w każdym przypadku okazała się większa niż deklarowane minimum (por. tab. 2).

Tabela 2. Średnie gęstości chmur punktów dotyczące obszarów analizowanych w artykule Table 2. Average point cloud density in areas discussed in the article

\begin{tabular}{|l|c|c|c|c|c|}
\hline \multirow{2}{*}{\begin{tabular}{c}
\multirow{2}{*}{$\begin{array}{c}\text { Stanowisko } \\
\text { archeologiczne }\end{array}$} \\
\cline { 2 - 6 }
\end{tabular}} & \multicolumn{5}{|c|}{ Średnia gęstość chmury punktów na m ${ }^{2}$} \\
\cline { 2 - 6 } & $\begin{array}{c}\text { tylko ostatnie } \\
\text { powroty }\end{array}$ & $\begin{array}{c}\text { wszystkie } \\
\text { powroty }\end{array}$ & ISOK & LAStools & \multicolumn{2}{c|}{ TerraScan } \\
\hline Chruścina & 7,11 & 10,41 & 2,64 & 2,91 & 3,07 \\
\hline Kruszyniec & 8,5 & 12,13 & 2,6 & 3,88 & 3,89 \\
\hline Bełcz Mały & 5,56 & 6,25 & 4,84 & 4,82 & 4,76 \\
\hline Wietrzychowice & 5,05 & 9,26 & 2,38 & 2,96 & 2,63 \\
\hline Grzybnica & 6,82 & 9,29 & 1,62 & 3,65 & 2,94 \\
\hline Eupawa 1 & 5,2 & 7,6 & 1,37 & 3,82 & 2,47 \\
\hline Eupawa 2 & 6,61 & 9,2 & 1,47 & 4,25 & 2,74 \\
\hline
\end{tabular}


W tej części artykułu autorzy skupią się na porównaniu poprawności dokonanej filtracji i klasyfikacji poziomu gruntu. W tym celu wykorzystane zostaną obrazy rastrowe wygenerowane $\mathrm{z}$ klasy gruntu zarejestrowanej w ISOK-u, LAStools i TerraScan. Konfrontacji zostaną poddane numeryczne modele terenu o rozdzielczości $0,5 \mathrm{~m} \times 0,5 \mathrm{~m}$ komórki $0,25 \mathrm{~m}^{2}$ ) oraz cieniowane modele terenu (wykonywane w interwałach $45^{\circ}$, kąt padania światła $15^{\circ}$ ). Cieniowane modele terenu zostały uzyskane w programie QGIS za pomocą wtyczki rastrowe analizy terenu. Aby wspomóc proces porównawczy, dla każdego obrazu rastrowego za pomocą wtyczki terrain profile został wykonany profil przedstawiający przekrój poprzeczny stanowiska. Rozdzielczość profilu jest uzależniona od kierunku, w którym została przeprowadzona linia cięcia oraz rozdzielczości obrazu rastrowego.

Pierwszym przykładem porównawczym jest średniowieczne grodzisko, znajdujące się w pobliżu miejscowości Chruścina, gmina Góra, woj. dolnośląskie. Grodzisko ma średnicę ok. $105 \mathrm{~m}$ i znajduje się na obszarze zalesionym. Ma dobrze czytelną formę terenową. Prawie w całości pokryte jest młodym lasem mieszanym. Jedynie niewielka, południowa część nasypu i pozostałości fosy nie są pokryte wysoką roślinnością. Grodzisko znajduje się na granicy dwóch arkuszy, które w tym przypadku były także granicą pomiędzy blokami ISOK o nr 4017 i 4048. Dlatego skanowanie zachodniej i wschodniej części stanowiska odbyło się w dwóch różnych terminach. Wschodnia część została zeskanowana 9 października 2011 r., zachodnią część zarejestrowano 28 października 2011 r. Podczas łączenia obu arkuszy nie stwierdzono większych przesunięć pomiędzy zestawami danych, co świadczy o precyzyjnie nadanej georeferencji i dobrym dopasowaniu bloków. Po wyświetleniu chmury punktów w 3D można było stwierdzić, że oba naloty odbyły się w różnych kierunkach. Porównanie zostało przeprowadzone dla obszaru o wymiarach $290 \mathrm{~m} \times 250 \mathrm{~m}$.

Porównanie wygenerowanych obrazów nie wykazało istotnych różnic jakościowych. Grodzisko zostało oddane w prawie identyczny sposób na każdym z trzech modeli. Jedynie znajdujące się na wschód od grodziska bruzdy orki, wykonanej przed laty pod nasadzenia lasu, zostały odtworzone bardziej szczegółowo w rastrach wykonanych na podstawie klasyfikacji pochodzącej z programów Terrascan i ISOK. Najmniej detali oddała w tym miejscu klasyfikacja LAStools. Jednak fakt ten nie ma większego wpływu na interpretację samego stanowiska i dokładność jego odwzorowania. Wykonany w programie QGIS profil terenu wykazał, że wygenerowane obrazy pokrywają się ze sobą. Jak się okazało, w każdym przypadku grodzisko zostało odwzorowane niemal identycznie. Największe różnice wynoszą zaledwie kilkanaście centymetrów.

Kolejnym stanowiskiem wykorzystanym w teście było grodzisko zlokalizowane w pobliżu miejscowości Kruszyniec, gm. Góra, woj. dolnośląskie (ryc. 1). Obszar ten został zeskanowany 28 października 2011 r. Stanowisko o średnicy ok. $60 \mathrm{~m}$ zachowało czytelną formę terenową i jest $\mathrm{w}$ całości porośnięte drzewami liściastymi w różnym wieku. Obszar testowy miał wymiary $130 \mathrm{~m} \times 145 \mathrm{~m}$. Znaczne rozbieżności w liczbie punktów gruntu, pochodzących z poszczególnych klasyfikacji 
(por. tab. 1), nie miały istotnego wpływu na poprawność odwzorowania grodziska. Wszystkie obrazy rastrowe prezentują się prawie identycznie, a wykonane przez stanowisko profile terenu wskazują, iż pokrywają się one ze sobą niemal idealnie.

Następnym przykładem, który posłużył do porównania skuteczności wykorzystanych narzędzi, było grodzisko znajdujące się w miejscowości Bełcz Mały, gm. Wąsosz, woj. dolnośląskie (ryc. 2). Zostało ono zeskanowane 28 października 2011 r. Stanowisko ma średnicę około 180 metrów i znajduje się w terenie otwartym. Samo grodzisko jest porośnięte drzewami liściastymi i stosunkowo gęstymi krzakami. Wokół obiektu jest widoczny obszar o wymiarach 400 m × 395 m, który poddano dalszej analizie.

Obrazy rastrowe uzyskane na podstawie poszczególnych klasyfikacji cechują pewne niewielkie różnice, szczególnie w obszarze majdanu grodziska. Najprawdopodobniej są to błędnie zaklasyfikowane punkty gruntu (być może z powodu gęstej roślinności). Wydaje się też, że pozostałe części stanowiska zostały oddane niemal

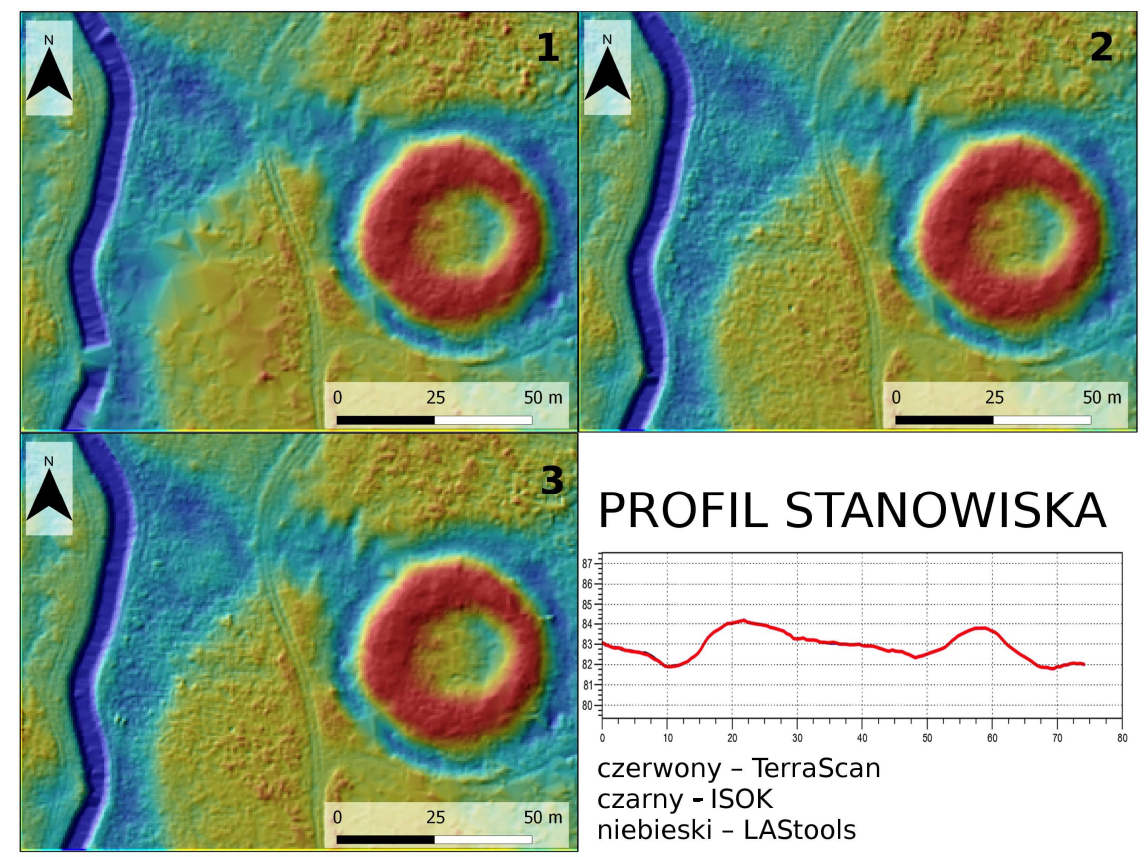

Ryc. 1. Grodzisko wczesnośredniowieczne w Kruszyńcu, gm. Góra, woj. dolnośląskie. Obrazy rastrowe wygenerowane na podstawie klasyfikacji: 1 - ISOK; 2 - LAStools; 3 - TerraScan. Kompozycja obrazu: pierwsza warstwa - cieniowany model terenu (azymut światła $315^{\circ}$, kąt padania $15^{\circ}$ ), $30 \%$ przezroczystości; druga warstwa - numeryczny model terenu

Fig. 1. Early medieval hillfort in Kruszyniec, commune Góra, dolnośląskie province. Rasters generated on the basis of classification: 1 - ISOK; 2 - LAStools; 3 - TerraScan. Composition of a picture: first level - shaded relief model (light azimuth $315^{\circ}$, incidence angle $15^{\circ}$ ), transparency of $30 \%$; second level digital terrain model 


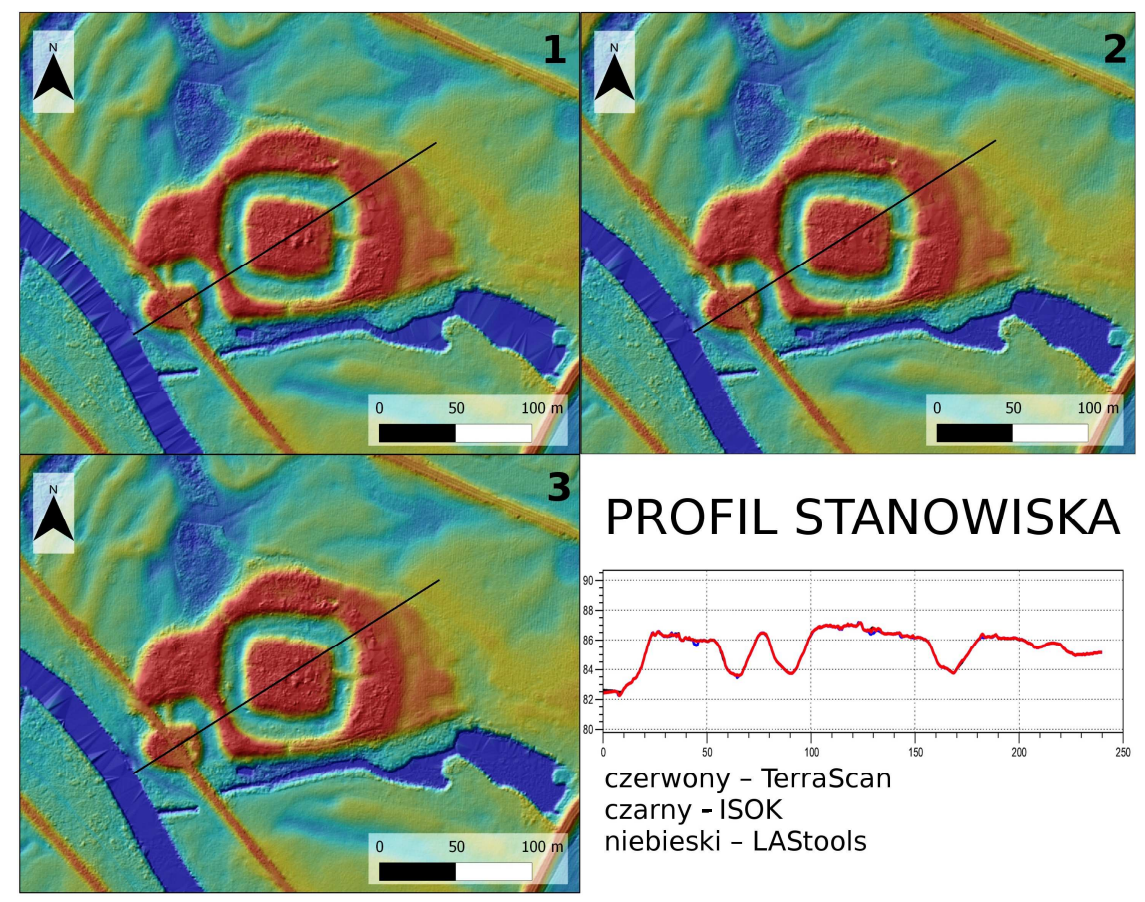

Ryc. 2. Grodzisko średniowieczne w Bełczu Małym, gm. Wąsosz, woj. dolnośląskie. Obrazy rastrowe wygenerowane na podstawie klasyfikacji: 1 - ISOK; 2 - LAStools; 3 - TerraScan. Kompozycja obrazu: pierwsza warstwa - cieniowany model terenu (azymut światła $315^{\circ}$, kąt padania $15^{\circ}$ ), $30 \%$ przezroczystości; druga warstwa - numeryczny model terenu

Fig. 2. Medieval hillfort in Bełcz Mały, commune Wąsosz, dolnośląskie province. Rasters generated on the basis of classification: 1 - ISOK; 2 - LAStools; 3 - TerraScan. Composition of a picture: first level shaded relief model (light azimuth $315^{\circ}$, incidence angle $15^{\circ}$ ), transparency of $30 \%$; second level digital terrain model

identycznie. Wykonany przekrój przez obiekty także nie wykazał większych różnic pomiędzy obrazami.

Kolejnym stanowiskiem poddanym testom było cmentarzysko megalityczne w Wietrzychowicach, gm. Izbica Kujawska, woj. kujawsko-pomorskie (ryc. 3). Na stanowisku znajduje się 5 grobowców kujawskich. Teren porośnięty jest lasem liściastym, który został przetrzebiony w najbliższym sąsiedztwie obiektów. Skaning laserowy tego miejsca został wykonany 1 maja 2011 r. Procesowi filtracji i klasyfikacji poddano pomiary uzyskane z obszaru o wymiarach $370 \mathrm{~m} \times 305 \mathrm{~m}$.

Wygenerowane modele terenu prezentują istotne rozbieżności między wszystkimi trzema chmurami punktów, które były podstawą do ich utworzenia. W tym przypadku klasyfikację ISOK należy uznać za całkowicie błędną. Pomiary grobowców zostały potraktowane w niej jako niska i średnia szata roślinna. W konsekwencji na obrazie rastrowym przedstawiającym grunt widoczne są jedynie puste miej- 


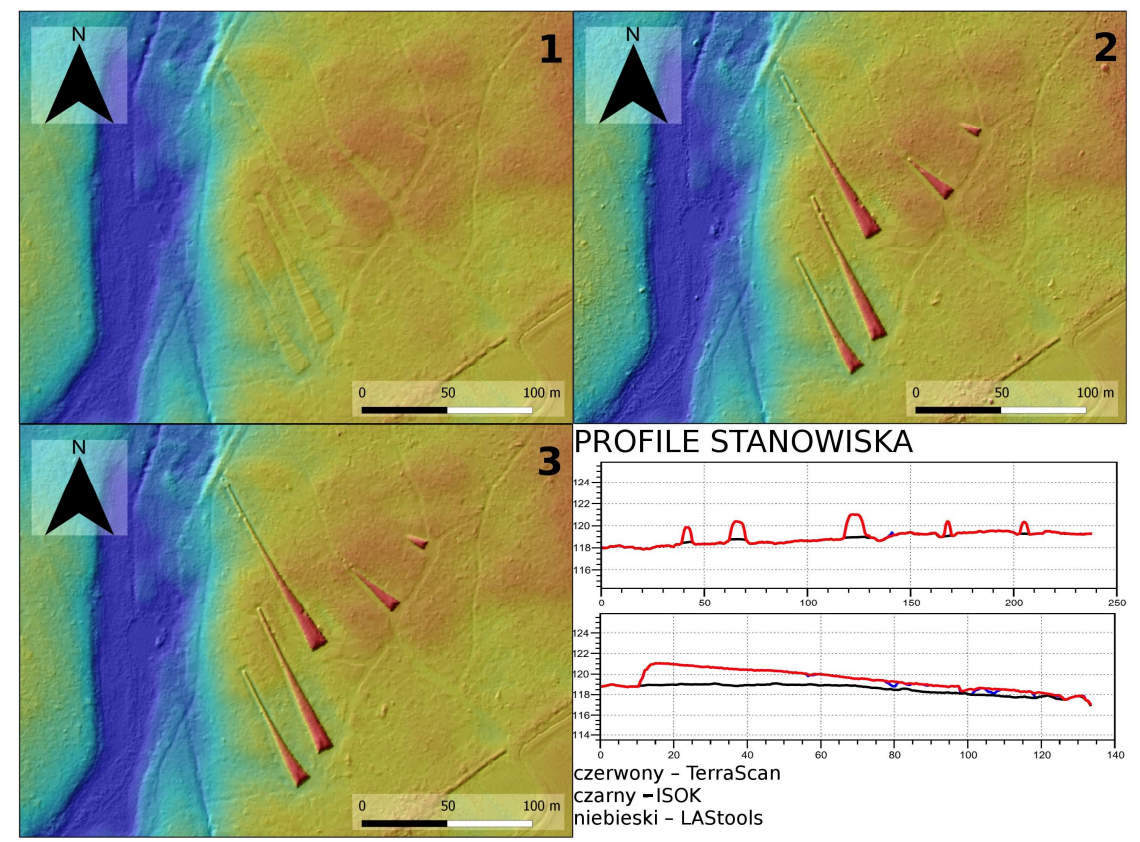

Ryc. 3. Cmentarzysko megalityczne w Wietrzychowicach, gm. Izbica Kujawska, woj. kujawsko-pomorskie. Obrazy rastrowe wygenerowane na podstawie klasyfikacji: 1 - ISOK; 2 - LAStools; 3 - TerraScan. Kompozycja obrazu: pierwsza warstwa - cieniowany model terenu (azymut światła $315^{\circ}$, kąt padania $15^{\circ}$ ), $30 \%$ przezroczystości; druga warstwa - numeryczny model terenu

Fig. 3. Megalithic cemetery in Wietrzychowic, commune Izbica Kujawska, kujawsko-pomorskie province. Rasters generated on the basis of classification: 1 - ISOK; 2 - LAStools; 3 - TerraScan. Composition of a picture: first level - shaded relief model (light azimuth $315^{\circ}$, incidence angle $15^{\circ}$ ), transparency of $30 \%$; second level - digital terrain model

sca, z których usunięte zostały obiekty. Algorytm filtracji i klasyfikacji gruntu programu LAStools poradził sobie o wiele lepiej z tym zadaniem. Dzięki niemu udało się zaklasyfikować prawidłowo większość pomiarów pochodzących z grobowców. Jednak także w tym przypadku wystąpiły pewne braki. Niektóre grobowce nie zostały w pełni odwzorowane. Kategoria gruntu została najdokładniej wydzielona w programie TerraScan, głównie dzięki możliwości ręcznej weryfikacji i korekty wyników filtracji automatycznej. Także w tym przypadku uzyskany obraz nie oddaje w pełni prawidłowo obiektów naziemnych. Nieścisłości w odwzorowaniu obiektów pojawiają się na odcinkach, gdzie mają one około 2,5 m szerokości. Dlatego najbardziej prawdopodobnej przyczyny tej sytuacji należy upatrywać w zbyt niskiej gęstości skanowania oraz pseudolosowym rozkładzie chmury punktów. Pośrednim powodem mogły być także gęste korony pobliskich drzew, które odbiły część wiązek emitowanych przez skaner. Łamany profil przeprowadzony w poprzek grobowców wskazuje na to, że rastry powstałe na podstawie klasyfikacji wykonanej w LAStools i TerraScan są bardzo podobne. Drugi profil, przeprowadzony przez 
najdłuższy z grobowców, prezentuje natomiast rozbieżności między wszystkimi trzema klasyfikacjami.

Interesujące wnioski przyniosła praca $\mathrm{z}$ danymi pochodzącymi ze stanowiska Grzybnica, gm. Manowo, woj. zachodniopomorskie (ryc. 4). Miejsce to zostało zeskanowane 3 marca $2012 \mathrm{r}$. Jest to powszechnie znany przykład unikatowego zespołu kręgów kamiennych, kurhanów oraz innych obiektów pochodzenia antropogenicznego. Omawiane stanowisko archeologiczne jest obecnie porośnięte lasem iglastym. Należy podkreślić, iż nie wszystkie obecne na nim obiekty mają wyraźną formę terenową i mogą być zarejestrowane przez LiDAR. Analizie został poddany obszar o wymiarach $420 \mathrm{~m} \times 630 \mathrm{~m}$.

Szczegółowa analiza obrazów rastrowych wykonanych na podstawie uzyskanych zestawów danych prowadzi do wniosku, że najgorszy efekt, $\mathrm{z}$ archeologicznego punktu widzenia, przyniosła klasyfikacja gruntu wykonana w ramach ISOK-u. Wprawdzie pozwoliła ona na odwzorowanie części obiektów archeologicznych, jednak ich szczegółowość jest zdecydowanie niższa niż na rastrach pochodzących

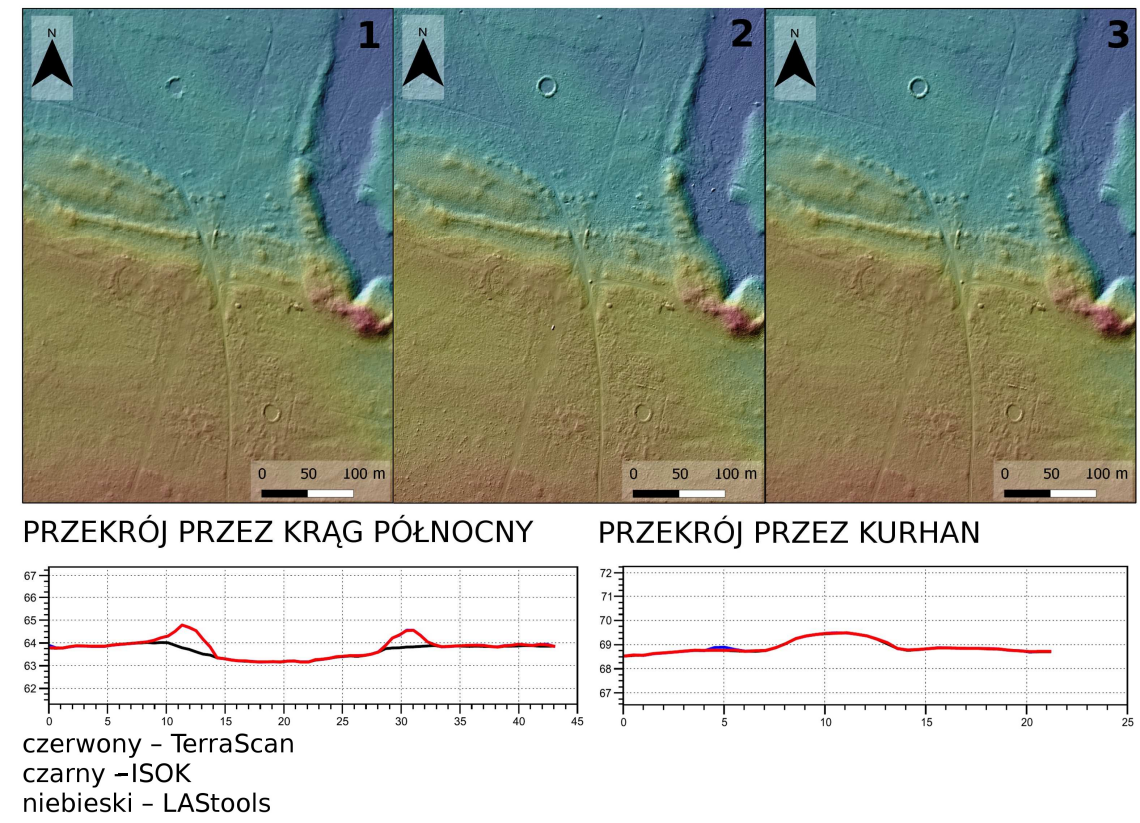

Ryc. 4. Grzybnica, gm. Manowo, woj. zachodniopomorskie. Zespół kręgów kamiennych i kurhanów. Obrazy rastrowe wygenerowane na podstawie klasyfikacji: 1 - ISOK; 2 - LAStools; 3 - TerraScan. Kompozycja obrazu: pierwsza warstwa - cieniowany model terenu (azymut światła $315^{\circ}$, kąt padania $15^{\circ}$ ), $30 \%$ przezroczystości; druga warstwa - numeryczny model terenu

Fig. 4. Grzybnica, commune Manowo, zachodniopomorskie province. Complex of stone circles and barrows. Rasters generated on the basis of classification: 1 - ISOK; 2 - LAStools; 3 - TerraScan. Composition of a picture: first level - shaded relief model (light azimuth $315^{\circ}$, incidence angle $15^{\circ}$ ), transparency of $30 \%$; second level - digital terrain model 
z klasyfikacji LAStools i TerraScan. Profile przeprowadzone przez trzy wybrane obiekty wykazują rozbieżności między uzyskanymi wynikami. Żaden z programów nie pozwolił jednak na wyróżnienie wszystkich znanych na omawianym stanowisku obiektów. Na rastrach brakuje niektórych kręgów kamiennych oraz kurhanów. Najprawdopodobniej niewystarczająca gęstość skanowania oraz obecność lasu iglastego porastającego stanowisko uniemożliwiły uzyskanie dostatecznej liczby odbić dla wszystkich obiektów. W tym przypadku program LAStools dostarczył obraz zawierający najwięcej detali. Widoczna jest na nim największa liczba obiektów, a nawet leśna orka, nieobecna na innych zobrazowaniach. Zawiera on jednak także największą liczbę błędnie zaklasyfikowanych punktów, znajdujących się do kilkunastu centymetrów nad powierzchnią ziemi.

Ostatnim analizowanym przykładem były skupiska budowli megalitycznych w pobliżu wsi Łupawa, gm. Potęgowo, woj. pomorskie. W związku z tym, że megality na tym obszarze występują w dwóch skupiskach - jedno około 800 metrów na północ od wsi, a drugie około $2 \mathrm{~km}$ na południowy-wschód - wydzielono tam dwa obszary. Oba miejsca porośnięte są obecnie lasem iglastym.

Teren $\mathrm{z}$ megalitami na północ od miejscowości został zeskanowany 7 maja $2011 \mathrm{r}$. Analizie poddano obszar o wymiarach $830 \mathrm{~m} \times 665 \mathrm{~m}$. Mimo rozbieżności w liczbie odbić gruntu, pochodzących z różnych klasyfikacji, wszystkie obrazy rastrowe uzyskane z chmur punktów w bardzo podobny sposób pozwoliły odwzorować obiekty archeologiczne. Wydaje się, że najwięcej błędnie sklasyfikowanych punktów w pobliżu poziomu gruntu pochodziło z programu LAStools, który pozwolił jednak także na odtworzenie największej liczby detali. Klasyfikacji oddającej najniższą liczbę punktów gruntu dokonano natomiast w ISOK-u (por. tab. 1), co jednak w tym przypadku nie wpłynęło negatywnie na odwzorowanie obiektów archeologicznych.

Wokół megalitów znajdujących się na południowy-wschód od wsi Łupawa wydzielono obszar o wymiarach $1130 \mathrm{~m} \times 870 \mathrm{~m}$. Teren ten był poddany skaningowi laserowemu 30 kwietnia $2011 \mathrm{r}$. W tym przypadku sytuacja była analogiczna do opisanej wcześniej. Nie stwierdzono istotnych rozbieżności pomiędzy wygenerowanymi rastrami. Także wiele profili przeprowadzonych przez obiekty wykazało duże podobieństwo pomiędzy omawianymi modelami terenu.

\section{PODSUMOWANIE WYNIKÓW BADAŃ}

Przeprowadzone powyżej zestawienie wskazuje przede wszystkim na dużą przydatność danych uzyskanych w ramach programu ISOK. Rozległy obszar poddany skaningowi oraz powszechna dostępność czynią z nich bogate źródło potencjalnych informacji przestrzennych na temat obiektów archeologicznych. Z punktu widzenia zastosowań archeologicznych negatywnie na jakość danych ISOK może wpływać natomiast zbyt niska gęstość czy nieodpowiedni termin, w którym zostało przeprowadzone skanowanie. Okoliczności te ograniczają wielkość rejestrowanych 
obiektów oraz precyzję ich odwzorowania. Sytuacja taka miała miejsce w przypadku omówionego w niniejszej pracy stanowiska archeologicznego w Grzybnicy. Część obiektów nie została tam zidentyfikowana, ponieważ skanowanie zostało przeprowadzone w okresie postępującej wegetacji roślin, a średnia gęstość pomiarów była niedostateczna.

Klasyfikacja chmury punktów dokonana w ramach ISOK-u okazała się w wielu przypadkach zadowalająca. Duże obiekty archeologiczne, takie jak omawiane przykłady grodzisk (Kruszyniec, Chruścina, Bełcz Mały), zostały zaklasyfikowane prawidłowo. Nie odbiegały one w istotny sposób od klasyfikacji przeprowadzonych w LAStools i TerraScan. Podobnie było z obiektami mającymi wyraźną formę terenową, takimi jak zespoły megalitów w Łupawie. Problem pojawił się natomiast w przypadku nieco mniejszych obiektów, znajdujących się w obszarze leśnym, które były tylko częściowo zaklasyfikowane prawidłowo (wspominana wcześniej Grzybnica) lub zostały potraktowane jako niska i średnia roślinność (Wietrzychowice). W związku z tym należy zakładać, że w niektórych warunkach klasyfikacja ISOK może okazać się zawodna i całkowicie pomijać nietypowe, niewielkie lub silnie zniwelowane obiekty.

Istotne wnioski przyniosło także porównanie jakości filtracji i klasyfikacji punktów pomiarowych gruntu w programach LAStools i TerraScan. W kilku przypadkach obie aplikacje przyniosły lepsze rezultaty niż ISOK. Pozwoliły na dokładniejsze odfiltrowanie chmur punktów dla Grzybnicy i precyzyjniejsze odwzorowanie obiektów. Dały także pozytywne rezultaty przy filtracji megalitów z Wietrzychowic. Na korzyść programu TerraScan przemawia wiele rozbudowanych opcji oraz możliwość manualnej edycji chmury punktów. Na niekorzyść natomiast: duża pracochłonność takiego rozwiązania, skomplikowana obsługa oraz fakt, że jest to oprogramowanie komercyjne. LAStools ma bardziej ograniczone możliwości edycji chmury punktów, nie da się w nim poprawić błędów spowodowanych przez działający automatycznie algorytm. Jednak, jak wykazało przeprowadzone porównanie, uzyskiwane rezultaty są zbliżone jakościowo do programu TerraScan. Ponadto charakteryzuje się on o wiele niższym nakładem pracy oraz nieporównywalnie krótszym czasem niezbędnym do wyodrębnienia punktów gruntu. Jest to także bardzo wydajne i zarazem stabilne narzędzie (podczas wszystkich testów program ani razu nie przestał działać).

Trudno natomiast mówić o prostym związku między zaklasyfikowaną liczbą punktów gruntu w poszczególnych programach a dokładnością odwzorowanych obiektów. Wydaje się, że klasyfikacja ISOK była wykonana w sposób najbardziej „ostrożny”, co w większości przypadków wpłynęło na najniższą liczbę punktów gruntu i niepełne oddanie lub brak niektórych obiektów. Przyczyną może być to, że ISOK ma na celu przede wszystkim stworzenie NMT, który będzie wykorzystywany do modelowania zagrożeń naturalnych. Dla tak zdefiniowanego zadania niewielkie obiekty archeologiczne nie mają żadnego znaczenia i mogą być pomijane. Należy też wziąć pod uwagę fakt, że klasyfikacji nie dokonują archeolodzy, a specjaliści z innych dziedzin. 
Różnice w klasyfikacjach wystąpiły także pomiędzy chmurami punktów z LAStools i TerraScan. W przypadku dużych obiektów (grodziska w Kruszyńcu, Chruścinie i Bełczu Małym) liczba wyodrębnionych punktów gruntu była bardzo zbliżona. W Wietrzychowicach mimo znacząco mniejszej liczby pomiarów gruntu zaklasyfikowanych przez TerraScan grobowce zostały odtworzone bardziej precyzyjnie (głównie dzięki dokonanej ręcznie korekcie) niż na podstawie danych z LAStools. LAStools wydzielił także znacznie większą liczbę punktów gruntu dla Grzybnicy i Łupawy. Na obrazach rastrowych, wykonanych na podstawie powyższych danych, można zaobserwować większą liczbę szczegółów (głównie dokładniejsze odwzorowanie współczesnej orki), ale także największe nagromadzenie błędnie zaklasyfikowanych pojedynczych punktów, znajdujących się do kilkunastu centymetrów nad poziomem gruntu. Sytuacja ta nie wpłynęła jednak negatywnie na możliwość identyfikacji zabytków archeologicznych. Prawdopodobnie jest to spowodowane ustawieniem wartości parametru offset na 0,1 . Pominięcie tego parametru spowodowałoby jednak, że algorytm odfiltrowałby zbyt wiele odbić gruntu, odrzucając także część pomiarów pochodzących z obiektów archeologicznych.

Na podstawie dokonanego porównania można stwierdzić, że LAStools jest interesującą alternatywą dla dostępnych na rynku programów komercyjnych. Obrazy rastrowe wygenerowane na podstawie sklasyfikowanych $\mathrm{w}$ nim chmur punktów charakteryzowały się dużą poprawnością i umożliwiały identyfikację obiektów archeologicznych. Zaobserwowane braki wynikały raczej z niedostatecznej gęstości skanowania niż z błędów programu. Różnice w uzyskiwanych efektach prowadzą do konkluzji, iż pracę z danymi ALS najlepiej rozpoczynać od etapu przetwarzania chmury punktów, ponieważ ma on determinujący wpływ na uzyskiwane rezultaty. Ponowna filtracja i klasyfikacja chmury punktów za pomocą odpowiednio dobranych ustawień może pozytywnie wpłynąć na ujawnianie się obiektów archeologicznych. Pominięcie tego kroku i przejście do pracy z gotowymi obrazami rastrowymi, przygotowanymi przez firmy nieposiadające doświadczenia w interpretacji obiektów archeologicznych, może spowodować, iż potencjał informacyjny tkwiący w niesklasyfikowanej chmurze punktów nie zostanie w pełni wykorzystany.

\section{ZAKOŃCZENIE}

W niniejszej pracy zwrócono szczególną uwagę na analizę obrazów rastrowych, ponieważ to przede wszystkim one, mimo iż mają charakter wtórny, są podstawą interpretacji archeologicznych. W wielu omówionych przypadkach występowały na nich obiekty, które nie powodowały trudności interpretacyjnych. Były to przede wszystkim łatwe do rozpoznania stanowiska o charakterystycznej formie terenowej - grodziska, grobowce kujawskie czy kręgi kamienne. Jednak nie w każdych oko- 
licznościach precyzyjne odwzorowanie zabytku gwarantuje, że zostanie on rozpoznany przez archeologa. Taka sytuacja wystąpiła w wypadku zespołu megalitycznego w Borkowie, gm. Malechowo, woj. zachodniopomorskie (ryc. 5). Mimo że obecne tam grobowce są widoczne w terenie, na obrazie rastrowym ich identyfikacja opierała się przede wszystkim na wiedzy pochodzącej z literatury ${ }^{35}$. Gdyby podobne relikty pojawiły się $\mathrm{w}$ niezidentyfikowanej wcześniej lokalizacji, najprawdopodobniej zostałyby niedostrzeżone przez interpretatora. Szczątkowa forma zachowania oraz niezbyt charakterystyczny kształt widziany z góry praktycznie uniemożliwiały rozpoznanie tego ważnego stanowiska. Stąd, poddając metodę krytyce, należałoby zadać pytanie nie tylko o jej ograniczenia techniczne, lecz także o wiedzę niezbędną do identyfikowania obiektów antropogenicznych.

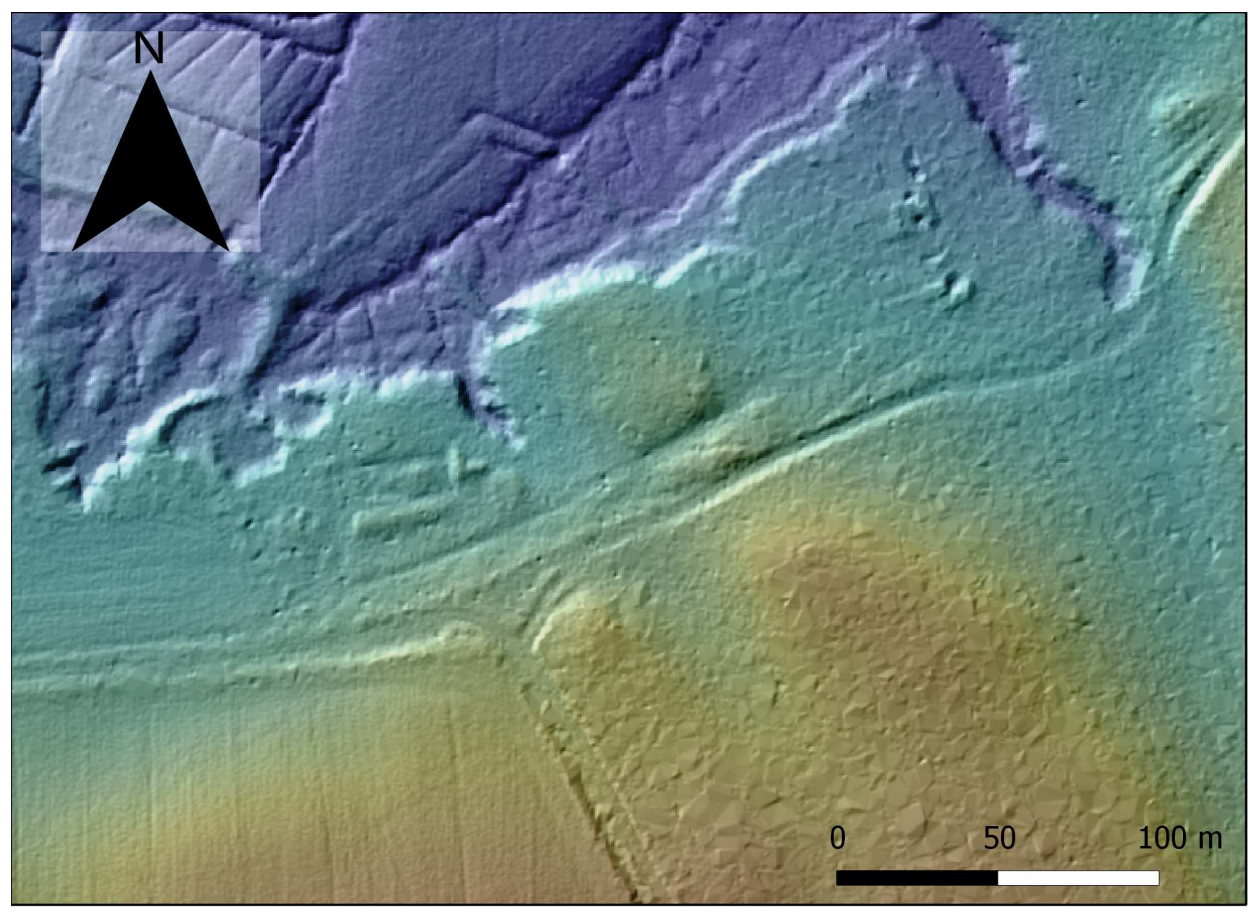

Ryc. 5. Borkowo, gm. Malechowo, woj. zachodniopomorskie. Zespół megalityczny. Obrazy rastrowe wygenerowane na podstawie klasyfikacji: 1 - ISOK; 2 - LAStools; 3 - TerraScan. Kompozycja obrazu: pierwsza warstwa - cieniowany model terenu (azymut światła $315^{\circ}$, kąt padania $15^{\circ}$ ), $30 \%$ przezroczystości; druga warstwa - numeryczny model terenu

Fig. 5. Borkowo, commune Malechowo, zachodniopomorskie province. Megalithic complex. Rasters generated on the basis of classification: 1 - ISOK; 2 - LAStools; 3 - TerraScan. Composition of a picture: first level - shaded relief model (light azimuth $315^{\circ}$, incidence angle $15^{\circ}$ ), transparency of $30 \%$; second level - digital terrain model

${ }^{35}$ Np. Wierzbicki 2005. 
Lotniczy LiDAR jest metodą, która otwiera przed archeologami nowe obszary badawcze. Być może za jego pomocą uda się wypełnić te „pustki osadnicze”, które powstały nie w wyniku braku osadnictwa na danym terenie, a z powodu słabości tradycyjnych metod prospekcji terenowej. Jak każda inna metoda, także ALS ma swoje ograniczenia. Nie jest on w stanie w sposób satysfakcjonujący odpowiedzieć na wszystkie zadawane przez archeologów pytania badawcze. Zasygnalizowana we wcześniejszym akapicie potrzeba posiadania wiedzy wstępnej, która umożliwia identyfikowanie stanowisk, świadczy o tym, że nie jest to metoda neutralna. Ponadto, analizowany jest nie sam krajobraz kulturowy, lecz jego cyfrowy model poddany odpowiedniej obróbce. W związku z tym nawet najbardziej charakterystyczne obiekty wymagają weryfikacji terenowej. Widoczne na obrazie rastrowym cmentarzysko kurhanowe może okazać się sąsiadującymi ze sobą nasypami, na których stały wiatraki, a grodzisko stożkowate - usypaną przed laty hałdą lub nowożytnym szańcem. Właśnie ze względu na specyfikę takich zobrazowań pojawiają się na nich elementy, dla których nie wypracowano jeszcze schematów interpretacyjnych. Dlatego nie wiadomo, jaką rolę w narracjach archeologicznych powinny odgrywać nieuchwytne dotychczas tradycyjnymi metodami obiekty, takie jak drogi, systemy pól, zagrody itd. Jak w każdym przypadku, także i tutaj przyrost bazy źródłowej pozwala odpowiedzieć na jedne pytania, nieuchronnie implikując inne, nieobecne dotychczas w dyskursie archeologicznym.

\section{BIBLIOGRAFIA}

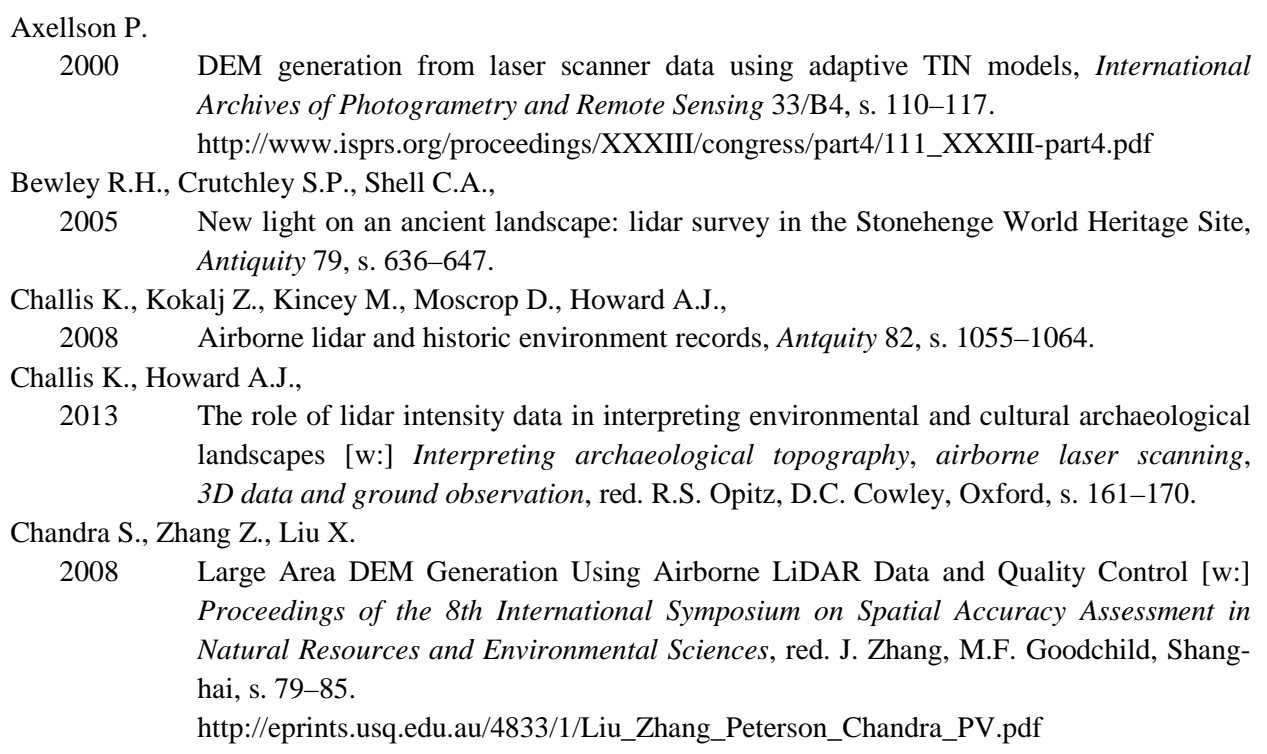


Cowley D.C., Opitz R.S.

2013 Interpreting archaeological topography: lasers, 3D data, observations, visualization and applications [w:] Interpreting archaeological topography, airborne laser scanning, $3 D$ data and ground observation, red. R.S. Opitz, D.C. Cowley, Oxford, s. 1-12.

Crutchley S., Crow P.

2009 The Light Fantastic: Using airborne laser scanning in archaeological survey, English Heritage, Swindon.

http://www.english-heritage.org.uk/publications/light-fantastic/light-fantastic.pdf

Crutchley S.

2013 Using lidar data - drawing on 10 year's experience at English Heritage [w:] Interpreting archaeological topography, airborne laser scanning, 3D data and ground observation, red. R.S. Opitz, D.C. Cowley, Oxford, s. 136-145.

Devereux B.J., Amable G.S., Crow P., Cliff A.D.

2005 The potential of airborne lidar for detection of archaeological features under woodland canopies, Antiquity 79, s. 648-660.

Devereux B.J., Amable G.S., Crow P.

2008 Visualisation of LiDAR terrain models for archaeological feature detection, Antiquity 82, s. $470-479$.

Doneus M., Briese C.

2011 Airborne Laser Scanning in forested areas - potential and limitations of an archaeological prospection technique [w:] Remote Sensing for Archaeological Heritage Management. Proceedings of the 11th EAC Heritage Management Symposium, Reykjavik, Iceland, 25-27.03. 2010, red. D.C. Cowley, Budapest, s. 59-76.

Doneus M., Kühteiber T.

2013 Airborne laser scanning and archaeological interpretation - bringing back the people [w:] Interpreting archaeological topography, airborne laser scanning, 3D data and ground observation, red. R.S. Opitz, D.C. Cowley, Oxford, s. 32-50.

Florinsky I.V.

2002 Errors of signal processing in digital terrain modeling, International Journal of Geographical Information Science 16, s. 475-501.

http://iflorinsky.narod.ru/Florinsky-2002a.pdf

Hesse R.

2010 LiDAR-derived Local Relief Models - a new tool for archaeological prospection, Archaeological Prospection 17, s. 67-72.

Hug C., Krzystek P., Fuchs W.

2004 Advanced LiDAR data processing with LAStools, International Archives of Photogrammetry and Remote Sensing 35, s. 832-837. http://www.isprs.org/proceedings/XXXV/congress/comm2/papers/240.pdf

Isenburg M.

2011 LAStools: converting, filtering, viewing, gridding, and compressing LiDAR data. http://www.cs.unc.edu/ isenburg/lastools.

Korzeniowska K., Łącka M.

2011 Generating DEM from LiDAR data - comparison of available software tools, Archiwum Fotogrametrii, Kartografii i Teledetekcji 22, s. 271-284.

Kraus K., Pfeifer N.

2001 Advanced DTM generation from LiDAR data, International Archives of Photogrammetry, Remote Sensing and Spatial Information Sciences 34, s. 23-30. http://www.ipf.tuwien.ac.at/publications/np_annapolis_2001.pdf 
Krištof O., Zakšek K., Kokalj Ž.

2013 Visualizations of lidar derived relief models [w:] Interpreting archaeological topography, airborne laser scanning, $3 D$ data and ground observation, red. R.S. Opitz, D.C. Cowley, Oxford, s. 100-114.

Królikowski J.

2012 ISOK od kuchni, Geodeta 7, s. 19-22.

Marszalik M.

2009 Modelowanie stref zagrożenia powodziowego z wykorzystaniem Numerycznego Modelu Terenu z lotniczego skaningu laserowego, Kraków [maszynopis pracy dyplomowej, AGH]. http://twiki.fotogrametria.agh.edu.pl/pub/PraceMagisterskie/WebHome/dyplomowa_Mar szalik.pdf

Opitz R.S.

2013 An overview of airborne and terrestrial laser scanning in archaeology [w:] Interpreting archaeological topography, airborne laser scanning, 3D data and ground observation, red. R.S. Opitz, D.C. Cowley, Oxford, s. 13-31.

Pietrzak J.

2012 Filtracja danych z lotniczego skaningu laserowego dla potrzeb NMT na przyktadzie wybranych programów, Kraków [maszynopis pracy dyplomowej, AGH].

Risbøl O.

2013 Cultivating the 'wileress' - how lidar can improve archaeological landscape understanding [w:] Interpreting archaeological topography, airborne laser scanning, 3D data and ground observation, red. R.S. Opitz, D.C. Cowley, Oxford, s. 51-62.

Sławik Ł., Zapłata R.

2011 LiDAR w archeologii - zagadnienia wprowadzające [w:] Digitalizacja dziedzictwa archeologicznego, wybrane zagadnienia, red. R. Zapłata, s. 207-232.

Soininen A.

2011a TerraScan User's Guide.

http://www.terrasolid.fi/en/users_guide

2011b TerraModeler User's Guide.

http://www.terrasolid.fi/en/users_guide

Szadkowski A.

2012 ISOK - co znajdziemy w zasobie?, Geodeta 7, s. 14-18.

Twardowski M., Marmol U.

2012 Wizualizacja i przetwarzanie chmury punktów lotniczego skaningu laserowego, Archiwum Fotogrametrii, Kartografii i Teledetekcji 23, s. 457-466.

Wężyk P.

2006 Wprowadzenie do technologii skaningu laserowego w leśnictwie, Roczniki Geomatyki 4/4, s. 119-132.

Wierzbicki J.

2005 Grobowiec megalityczny z Borkowa, stan. 1, gm. Malechowo, woj. zachodniopomorskie. Jedyny grób korytarzowy na ziemiach polskich? [w:] Historia i kultura Ziemi Stawieńskiej, Gmina Malechowo, t. 5, red. W. Rączkowski, J. Sroka, Sławno, s. 93-112.

Zakšek K., Kokalj Ž., Oštir K.

2011 Application of sky-view factor for the visualization of historic landscape features in lidar-derived relief models, Antiquity 85, s. 263-273.

Źródła internetowe

http://isok.imgw.pl/

http://www.codgik.gov.pl/zasob/372-numeryczne-dane-wysokosciowe.html 


\section{ARCHAEOLOGY IN THE POINT CLOUD. COMPARING RESULTS OF FILTRATION AND CLASSIFICATION OF THE GROUND POINTS IN ISOK PROJECT WITH RESULTS OBTAINED WITH LAStools AND TERRASOLID SOFTWARE}

S u m m a r y

Airborne laser scanning (hereinafter also referred to as ALS) is one of the most revolutionary methods used in archeology in the recent years. Its biggest advantage is the possibility of recording archaeological sites inaccessible to conventional prospection (located in forests, covered by dense vegetation or in difficult and inaccessible terrain). ALS allows to obtain detailed information about the topography of large areas. So far, the biggest disadvantages of this approach have included: the costs of organizing photogrammetric flight, the cost of software for processing acquired data and the time needed to process them.

"Computerized Information System of Country Protection from Extraordinary Hazards" (Polish: ISOK) implemented in Poland several years ago may change the way of thinking about ALS. Broad access to products prepared under this project, and relatively low cost of provided data can, very effectively, encourage archaeologists to use airborne laser scanning technology. In that case the biggest challenge would be not to organize photogrammetric flight, but to gain access to the appropriate software.

Working with LiDAR data requires specialized software. One of the most popular among them is the solution of Terrasolid, operating in a CAD environment. The cost of buying such software is several thousand euro. The ability to use it in a proper way requires many hours of practice. Those circumstances greatly limit the chances of widespread use of Terrasolid software in archeology.

However, there are alternatives. One of them is LAStools software developed by Martin Isenburg. It can be used for the efficient preparation and management of products of airborne laser scanning. This powerful tool allows, among others, for classification of the point cloud. It is also possible to generate other products based on LiDAR data such as: digital terrain models (DTM), digital surface models (DSM), land cover map contour, etc. So, in terms of functionality needed by archaeologists, it practically comes up to commercial software.

In this paper we verified the effectiveness of ground filtration algorithm implemented in LAStools software. To do this we filtrated and classified ground points with different software sets. We used two applications from the package of Terrasolid - TerraScan and TerraModeler. Digital terrain models generated on the basis of points classified in TerraScan were used as a reference and compared with results obtained from LAStools and classification made by the ISOK project. The objectives of the research were to test the alternatives of expensive commercial software. We also examined usefulness of ISOK data for archaeological purposes.

For the research, we selected different archaeological sites, both in terms of chronology and landforms. Those include: hillforts in Bełcz Mały, Kruszyniec, Chruścina, stone circles and barrows of Grzybnica, megaliths from Łupawa and Wietrzychowice.

The work scope clearly confirmed the usefulness of the data collected in the frame of the ISOK project. In particular, it showed advantages of the method in forested areas, where identification of the anthropogenic remains is far insufficient. Classification of ISOK project in some cases proved to be unreliable. For example, megaliths of Wietrzychowice have been incorrectly 
assigned to the classes of vegetation, and because of that, they did not appear on the generated digital terrain models. Therefore, we believe that the best solution while working with data from the ISOK project is to order the data source in point cloud format of LAS and do the filtering and classification of ground with different setups to check the most satisfactory result.

Our tests have also shown that the point cloud can be successfully prepared by using LAStools program, released under LGPL license. This solution is not too complicated to use and should meet the expectations of archaeologists in every way. Moreover, in selected test areas of ground filtration algorithm LAStools properly attributed points to the ground class, taking into account the archaeological sites of various landforms.

Translated by Grzegorz Kiarszys, Grzegorz, Szalast 